Brazilian Journal of Microbiology (2009) 40: 655-662

ISSN 1517-8382

\title{
PSEUDOMONAS AERUGINOSA KUCD1, A POSSIBLE CANDIDATE FOR CADMIUM BIOREMEDIATION
}

\author{
Sangram Sinha, Samir Kumar Mukherjee* \\ Department of Microbiology, University of Kalyani, Kalyani 741235, INDIA \\ Submitted: June 26, 2008; Returned to authors for corrections: October 10, 2008; Approved: May 03, 2009.
}

\begin{abstract}
A cadmium $(8 \mathrm{mM})$ resistant Pseudomonas aeruginosa strain KUCd1 exhibiting high $\mathrm{Cd}$ accumulation under in vitro aerobic condition has been reported. The isolate showed a significant ability to remove more than $75 \%$ and $89 \%$ of the soluble cadmium during the active growth phase from the growth medium and from Cd-amended industrial wastewater under growth supportive condition. Transmission electron microscopy (TEM) and energy dispersive X-ray spectroscopy (EDXS) suggest the presence of $\mathrm{Cd}$ in the cells from mid-stationary phase. The cell fractionation study revealed membrane and periplasm to be the major accumulating site in this strain. The chemical nature of the accumulated $\mathrm{Cd}$ was studied by X-ray powder diffraction analysis.
\end{abstract}

Key words: Pseudomonas aeruginosa, Cadmium, Bioremediation

\section{INTRODUCTION}

Among the metals or metalloids arsenic, cadmium, mercury, lead and chromium have been known to be extremely toxic at low concentration (29) although they have no significant biological function so far reported. Cadmium causes reduced growth rate, long lag phase, lower cell density and may even cause death of bacteria at levels below 1 ppm $(2,14,15,19,24)$. Bacteria detoxify heavy metals in a variety of different ways. Some bacteria employ plasmid mediated efflux system that energetically drives out $\mathrm{Cd}, \mathrm{Zn}$ and many other toxic metal ions $(9,18,26)$. Whereas many bacteria adsorb heavy metals to their cell wall $(7,8,17,23,32)$ or bind metal ions to proteins like metallothioneins, metal-peptide etc
(10). Microbes often do precipitate heavy metals in the form of insoluble phosphate, sulfide or others to reduce their bioavailability $(2,3,12,28)$.

In the present perspective of metal pollution research, the urgency lies in studying metal resistance mechanisms in microbes, which might shed light to develop a potential candidate for bioremediation $(6,31)$. Here we report a $\mathrm{Cd}$ resistant Pseudomonas aeruginosa KUCd1, which could effectively accumulate $\mathrm{Cd}$ rendering the strain as a possible effective candidate for reclamation of environment. The cellular localization of accumulated cadmium and its chemical nature were analyzed to find out the possible mechanism of $\mathrm{Cd}$ detoxification in this test strain. 
Sinha, S. et al.

\section{MATERIALS AND METHODS}

\section{Bacterial strain}

The isolation and characterization of the strain Pseudomonas aeruginosa KUCd1, used in this study has previously been done (27) by biochemical tests and $16 \mathrm{~S}$ rDNA sequence (GenBank Accession No. EF 644569 at NCBI database) analysis. This gram-negative rod-shaped motile bacterial strain was found to remarkably resistant to other heavy metals as well. The order of toxicity of the metals to the bacterium on both solidified and liquid medium was found to be $\mathrm{Cr}>\mathrm{Co}>\mathrm{Cu}>\mathrm{Cd}>\mathrm{Ni}>\mathrm{Zn}>\mathrm{Mn}$. It has also showed cadmium-induced siderophore production (27). The culture is being maintained in nutrient agar media $(\mathrm{pH} \mathrm{7)}$ supplemented with $2 \mathrm{mM}$ cadmium as $\mathrm{CdCl}_{2}$.

\section{Cadmium tolerance ability of KUCd1}

The $\mathrm{Cd}$ tolerance ability of the bacterial isolate was tested with increasing concentration of $\mathrm{Cd}(1$ to $10 \mathrm{mM})$ in undefined nutrient agar medium and compared that in the defined Tris minimal medium (21) supplemented with $0.8 \%$ glucose (TMMG).

\section{Cadmium accumulation and removal assay}

Twelve hours grown cell suspension from TMMG $(\sim 4$ $\log$ number of CFU.ml ${ }^{-1}$ ) was inoculated to same medium having $3 \mathrm{mM}$ of $\mathrm{Cd}$ and incubated on a shaking incubator at $37^{\circ}$. Cells were harvested at $24,36,48,72$ and $96 \mathrm{~h}$ of incubation by centrifugation $\left(11000 \mathrm{x} g\right.$ for 10 minutes at $\left.4^{\circ}\right)$. Because of less cell mass production by the strain at the maximum tolerance level of $\mathrm{Cd}(8 \mathrm{mM})$, in this experiment 3 $\mathrm{mM} \mathrm{Cd}$ was used to have substantial biomass yield. The $\mathrm{pH}$ change in the medium was also monitored in both the Cdadded and Cd-free sets. The metal content in the medium supernatants were analyzed using an atomic absorption spectrophotometer (Perkin Elmer AAnalyst 400, USA).
Percentages of $\mathrm{Cd}$ removal by the cell mass from the culture were calculated by taking difference between the initial metal content in the culture media and that in the time of sampling. Cell-free sets were maintained for each treatment regime to determine the artifacts might arise due to the metal sorption on the glass surface of the culture container.

\section{Survival of the strain in industrial wastewater}

Industrial wastewater that contained little $\mathrm{Cd}(0.01 \mathrm{mM})$ and nutrients was collected locally, $\mathrm{pH}$ was adjusted to 7.2, sterilized and $\mathrm{Cd}$ was added as sterilized $\mathrm{CdCl}_{2}$ solution to it for having final concentration of $0.6 \mathrm{mM}$ and $0.4 \mathrm{mM}$ of $\mathrm{Cd}$ separately in two different conical flasks. Lower concentrations of $\mathrm{Cd}$ were applied in this experiment to get a substantial bacterial cell mass under nutrient limited condition. One $\mathrm{ml}$ of $12 \mathrm{~h}$ grown cell suspension $(\sim 4 \log$ number of CFU.ml ${ }^{-1}$ ) culture grown in TMMG was added to the experimental sets containing $50 \mathrm{ml}$ wastewater with 0.6 $\mathrm{mM}$ and $0.4 \mathrm{mM} \mathrm{Cd}$, and to a control set without added $\mathrm{Cd}$. The three experimental sets were then kept at $30^{\circ}$ on an incubator shaker at $110 \mathrm{rpm}$. At every $24 \mathrm{~h}$ of interval, sample was drawn to count colony forming units (CFU) by dilution plating on nutrient agar plates having $3 \mathrm{mM}$ of $\mathrm{Cd}$.

Effect of nutrient supplementation on growth in wastewater and $\mathrm{Cd}$ removal

Sterilized industrial wastewater $(\mathrm{pH}$ 7.2) was supplemented with analytical grade of $\mathrm{NH}_{4} \mathrm{Cl}\left(300 \mathrm{mg} . \mathrm{L}^{-1}\right)$, Glucose $\left(0.5\right.$ g. $\left.\mathrm{L}^{-1}\right)$ and $\mathrm{KH}_{2} \mathrm{PO}_{4}\left(200 \mathrm{mg} . \mathrm{L}^{-1}\right)$ as $\mathrm{N}, \mathrm{C}$ and $\mathrm{P}$ sources respectively to provide sufficient conditions for growth. One $\mathrm{ml}$ of $12 \mathrm{~h}$ grown cell suspension $(\sim 4 \log$ number of CFU.ml ${ }^{-1}$ ) in TMMG was added to the $250 \mathrm{ml}$ conical flask containing $50 \mathrm{ml}$ of wastewater with $\mathrm{Cd}(0.6$ $\mathrm{mM}$ ) or without added $\mathrm{Cd}$. The flasks were kept at $30^{\circ}$ on shaking incubator for $96 \mathrm{~h}$. The samples were drawn at $24 \mathrm{~h}$ 
interval to determine the viable cell numbers for each set by dilution plate technique on a nutrient agar medium having 3 $\mathrm{mM}$ Cd. Culture suspension was withdrawn from each set at $24 \mathrm{~h}$ intervals and centrifuged at $11000 \mathrm{x}$ g for $15 \mathrm{~min}$. The $\mathrm{Cd}$ content in the supernatant was analyzed and control sets were maintained as described earlier. Cd removal (\%) was calculated by taking difference of the metal content of the cultures at time zero and at the time of sampling.

\section{TEM and EDXS study}

Bacterial cells grown for $48 \mathrm{~h}$ in Cd-added (3 mM) TMMG medium were harvested by centrifugation and were repetitively washed with phosphate buffer saline $(\mathrm{pH}$ 7.2). The cells were fixed by treating with equal volume of $3 \%$ glutaraldehyde in the same buffer solution for $1 \mathrm{~h}$, post-fixed with $1 \%$ osmium tetroxide (31). The cells were then gradually dehydrated in ethanol and finally embedded in SPURR's resin. Thin sections were cut with a Dupont diamond knife in an LKB Ultramicrotome, and were loaded in formvar carbon-coated grid and observed in TEM (JEOL $100 \mathrm{CX}$, Japan) at varied magnifications. EDXS analysis of the sample was done with EX-64165 JMU, JEOL (Japan).

\section{X-ray powder diffraction study}

The X-ray diffraction pattern of the $\mathrm{Cd}$ treated $(3 \mathrm{mM})$ or untreated lyophilized cells after $48 \mathrm{~h}$ of growth of the test strain were recorded in a Seifert 3000P Powder Diffractometer using monochromatic $\mathrm{Cu} K \alpha_{1}$ radiation $(\lambda=$ $1.540598 \AA$ ) The diffraction spectra were recorded in a range between $10^{\circ}$ to $90^{\circ}(2 \theta)$ with a step length of $0.02^{\circ}(2 \theta)$. To identify the cadmium salt, the experimental X-ray diffraction pattern was compared with powder diffraction standards.

Distribution pattern of accumulated $\mathrm{Cd}$ in the subcellular fractions
For localizing the site of intracellular $\mathrm{Cd}$ accumulation in the bacterial strain, $\mathrm{Cd}(3 \mathrm{mM})$ exposed cells after $48 \mathrm{~h}$ of growth were fractionated into cellular, total membrane and periplasmic parts (11). Forty milliliter each of Tris- $\mathrm{HCl}$ buffer $(0.2 \mathrm{M}, \mathrm{pH} 7.1)$ and sucrose $(40 \%$, w/v) were used to suspend metal loaded cell pellets and kept for equilibration (30 min). Then the cells were centrifuged and quickly suspended in $80 \mathrm{ml} \mathrm{MgCl} 2(0.5 \mathrm{mM})$ in an ice bath to release the periplasmic fraction. The post-shock cells were disrupted by sonication and the homogenate was centrifuged $(90,000 \mathrm{~g}$ for $1 \mathrm{~h}$ ) to separate total membrane components and the cytosol. Amount of Cd retained in the sub-cellular fractions was quantified as described before following acid digestion.

\section{Sulfide production test}

The bacterial strain was inoculated to Sulfide Indole Motility (SIM) medium (30 mg. $\mathrm{ml}^{-1}$ peptone, $3 \mathrm{mg} \cdot \mathrm{ml}^{-1}$ beef extract, $0.2 \mathrm{mg} \cdot \mathrm{ml}^{-1}$ ferrous ammonium sulfate, $0.025 \mathrm{mg} \cdot \mathrm{ml}^{-1}$ sodium thiosulfate) agar tube and incubated at $30^{\circ}$ for observing the black color along the line of stab inoculation.

\section{Protein quantification}

Total cellular protein or in the sub-cellular fractions was estimated by a standardized method (5) using bovine serum albumin as standard.

\section{RESULTS AND DISCUSSION}

The strain could tolerate as high as $8 \mathrm{mM}$ of $\mathrm{Cd}$ in the nutrient agar medium at $\mathrm{pH}$ 7.2. However, the strain was found to tolerate maximum of $4 \mathrm{mM} \mathrm{Cd}$ concentration in defined TMMG medium (data not shown). The discrepancy in $\mathrm{Cd}$ resistance showed by the strain in the two different media may be explained by the fact that complexation of $\mathrm{Cd}$ with complex ingredients in the undefined NA medium might have lowered $\mathrm{Cd}$ availability around and therefore its toxicity 
(20). Nevertheless, the level of Cd tolerance of this strain under aerobic conditions is significant in comparison to that of the earlier reported pseudomonad strains $(30,31)$.

Bioaccumulation of $\mathrm{Cd}$ by bacteria have been studied by many workers $(4,8)$, among those Pseudomonas aeruginosa CW-96-1 (31) has shown to remove Cd most efficiently from medium having $1 \mathrm{mM} \mathrm{Cd}$, however, the strain used in this study could remove significantly from medium having $3 \mathrm{mM}$ $\mathrm{Cd}$ under aerobic condition. Maximum $\mathrm{Cd}$ removal by KUCd1 strain occurred after the mid stationary phase. Since growth phase is a biotic variable that can affect metal uptake by a bacterial population, the metal removal capacity was investigated during the different growth phases of the test strain. The $\mathrm{pH}$ of the medium was found to be progressively alkalized in both the $\mathrm{Cd}$ added and control medium. However, in the $\mathrm{Cd}$ added medium the $\mathrm{pH}$ change observed to be more ( $\mathrm{pH} 7$ to $\mathrm{pH} 8.5)$ than the $\mathrm{Cd}$-free set $(\mathrm{pH} 7$ to $\mathrm{pH}$ 7.5) after 96 hours of growth. It seems increase in $\mathrm{pH}$ is likely to be linked with transformation of $\mathrm{Cd}$ to an insoluble species within the cell or around, a phenomenon observed in other bacterial strain as well (4). For better understanding, the contribution of physiological and intracellular oxidation states (1) of the cell on $\mathrm{Cd}$ detoxification warrants further investigation. More than $75 \%$ soluble cadmium was removed from the culture medium after 96 hours i.e. during stationary phase (Fig. 1). Cell mass dependency on $\mathrm{Cd}$ removal was found during active growth phase, however, steady removal of $\mathrm{Cd}$ in the stationary phase was found to be independent of viable cell mass increment which might be due to the physical adsorption significantly by the dead cell mass as interpreted earlier (13). In cell free controls abiotic precipitation or complexation was taken into consideration and found insignificant.

Effective bioremediation of heavy metals from the polluted site depends on the survival of the organisms and

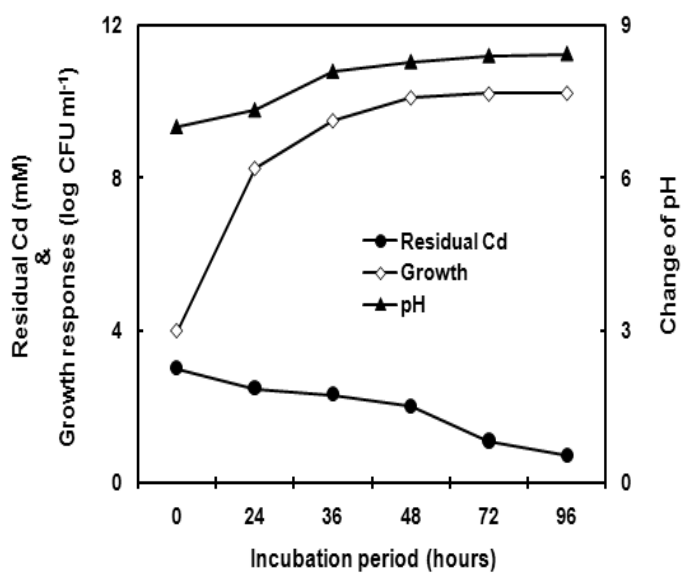

Figure 1. Variation of $\mathrm{pH}$ and $\mathrm{Cd}$ content in the medium along incubation period in response to the growth of KUCd1 under aerobic condition in TMMG medium having $3 \mathrm{mM}$ of $\mathrm{Cd}$.

availability of nutrients under such conditions. The bacterial strain was subjected to grow in the industrial wastewater added with Cd. The data (Fig. 2) showed that the viable cell number decreased comparably in the entire test regimes with the progress of time. Such declining in survival ability might be due to the nutritional scarcity. Survival efficiency and consequently cell mass of the bacterial strain were increased significantly in the wastewater when additional nutrients were supplied (Fig. 2). Accordingly, Cd removal capacity of the strain from wastewater having $0.6 \mathrm{mM} \mathrm{Cd}$ was evaluated in nutrient supplemented condition and without adding nutrient. Considering level of $\mathrm{Cd}$ content in the industrial wastewater, and to maintain the survival of microflora and also to ensure adequate contact between the biomass and the pollutant metals, in this experiment $0.6 \mathrm{mM}$ of $\mathrm{Cd}$ was used to evaluate Cd removal ability of this strain. It was observed (Fig. 3) that under nutrient sufficient condition the bacterial strain removed almost $89 \%$ of the $\mathrm{Cd}$ from the wastewater after 96 hours. But when the strain was grown in nutrient deficient condition it removed less than $20 \%$ of $\mathrm{Cd}$ from the 
wastewater. It might be due to the less cell mass production, both viable and dead cell mass, under nutrient depleted condition.

To localize the intracellular site of accumulated $\mathrm{Cd}$, cells of KUCd1 were observed under TEM. The transmission electron micrograph (Fig. 4) showed electron dense grains in the cytosol and towards the cell envelope. For further analysis of the electron dense bodies, EDXS study was performed. The data showed the peak for $\mathrm{Cd}$ in the treated cells (Fig. 5). The strain could produce sulfide when grown on SIM agar tube as indicated by black coloration along the line of stab inoculation. This production of sulfide might confer $\mathrm{Cd}$ resistance in this strain for its survival under $\mathrm{Cd}$ stress and it detoxifies $\mathrm{Cd}$ by converting it into insoluble $\mathrm{CdS}$ as reported earlier $(25,30,31)$. So biochemical and EDXS data predict that the test strain might convert cadmium into $\mathrm{CdS}$ under $\mathrm{Cd}$ stress condition. The powdered X-ray diffraction data of the $\mathrm{Cd}$ loaded cells revealed the chemical nature of the accumulated Cd within the cell (Fig. 6). The broadened nature of the peaks in the diffractogram indicates the existence of amorphous phase(s) in the sample. However, from the intensity distribution pattern of the diffractogram, existence of a peak at $2 \theta=31.54$ can readily be understood. Based on the $d$ value, the peak at $2 \theta=31.54$ might be assigned as $\mathrm{CdS}$. In the $\mathrm{Cd}$ untreated set there was no such conspicuous peak for CdS. This observation supports the earlier findings in the present study that the strain tolerated such high level of $\mathrm{Cd}$ by depositing insoluble $\mathrm{CdS}$. However, the processes of physical adsorption or complexation of $\mathrm{Cd}$ by the dead cell mass could not be eliminated in this strain because of higher amount of Cd removal during stationary phase and warrant further investigation.

The distribution of $\mathrm{Cd}$ in the cell was further investigated through sub-cellular fractionation coupled to its quantitative

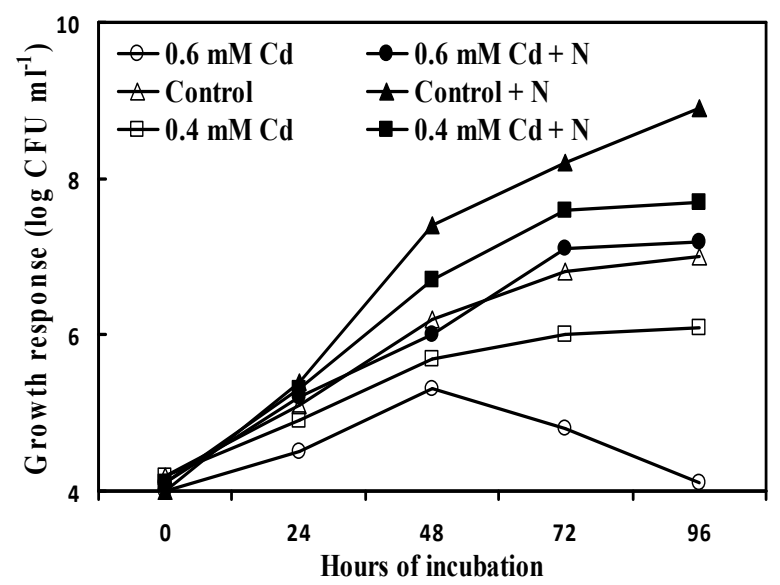

Figure 2. Survival of KUCd1 in the industrial wastewater having $0.6 \mathrm{mM}$ or $0.4 \mathrm{mM} \mathrm{Cd}$ with $(+\mathrm{N})$ or without supplemented extra nutrient. Controls are without added $\mathrm{Cd}$. Colony forming units $(\mathrm{CFU})$ were enumerated on nutrient agar supplemented with $3 \mathrm{mM}$ of Cd.

estimation by atomic absorption spectroscopy. The result showed that a major fraction $(84.43 \%)$ of total intracellularly accumulated $\mathrm{Cd}$ was found to be associated with the envelope with a maximum $(55.98 \%)$ by the periplasm followed by membrane component $(27.69 \%)$. The cytoplasm accounted for very low $\mathrm{Cd}$ deposition (15.57\%) of the total uptake (Table 1). This observation is supportive of earlier findings on membrane-associated accumulation of $\mathrm{Ni}$ in $P S$. aeruginosa (22) and of $\mathrm{Cd}$ in E. coli (16), where the membrane retained more than $50 \%$ of the total accumulated metal. Nevertheless, the strain exhibits diversified strategies to detoxify $\mathrm{Cd}$, it might be both due to cytosolic or periplasmic acquisition and physical adsorption on the surface by dead or live cells.

This strain shows promise for successful microbiological detoxification of $\mathrm{Cd}$ for both in situ or ex situ bioremediation of Cd-contaminated sites having appropriate growth sufficient 
conditions. The strain showed its possibility as well to be applied in the Cd contaminated agricultural land as a good bioremediation agent (27), although the extent of Cd removal under actual metal-polluted site conditions warrants further study.

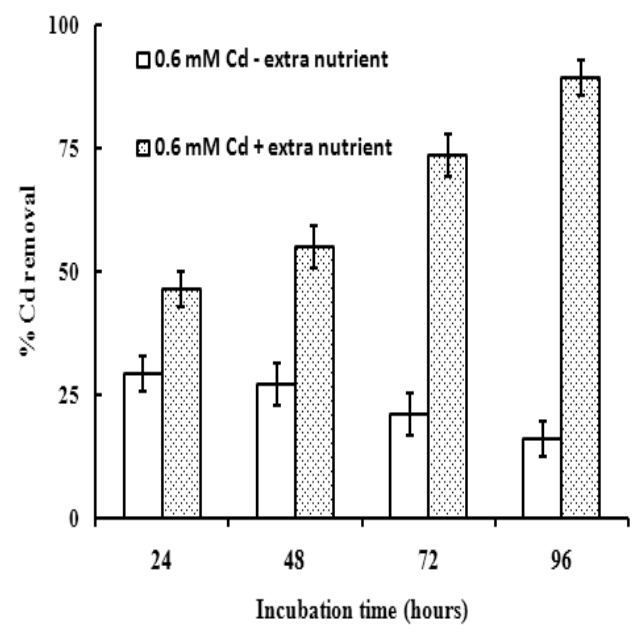

Figure 3. Cadmium removal by KUCd1 from wastewater with or without added nutrient with the function of time (hour of incubation). Data are the mean of five replications with standard error bars.

Table 1. Intracellular distribution of accumulated cadmium in KUCd1 grown for $48 \mathrm{~h}$ in TMMG medium supplemented with $3 \mathrm{mM} \mathrm{Cd}$ as $\mathrm{CdCl}_{2}$.

\begin{tabular}{lc}
\hline Cell fraction & $\mu \mathrm{g} \mathrm{Cd} \mathrm{per} \mathrm{mg} \mathrm{protein}$ \\
& \\
\hline Total cell & $5.020( \pm 0.860)$ \\
Periplasm & $2.810( \pm 0.263)$ \\
Total membrane & $1.390( \pm 0.680)$ \\
Cytoplasm & $0.782( \pm 0.026)$
\end{tabular}

${ }^{\mathrm{a}}$ data are the mean of 5 sets with standard error values.
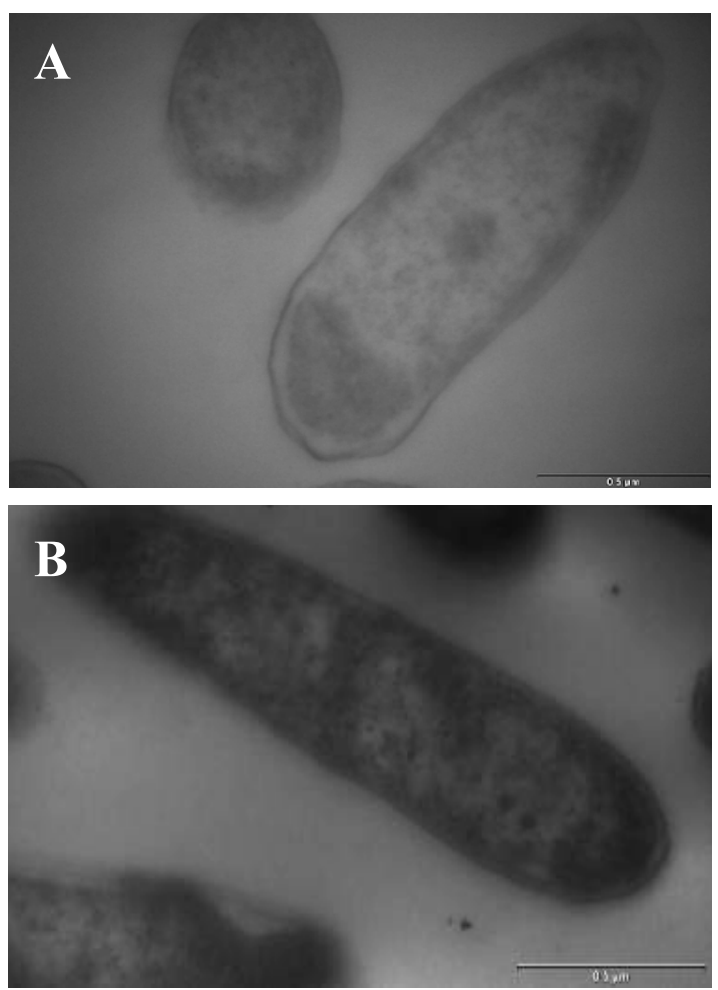

Figure 4. TEM analysis of the bacterial cells grown for $48 \mathrm{~h}$ in TMMG medium without (A) or with $3 \mathrm{mM}$ of $\mathrm{Cd}$ (B) showing electron dense grains distributed within the cell $(\mathrm{Bar}=0.5 \mu \mathrm{m})$.

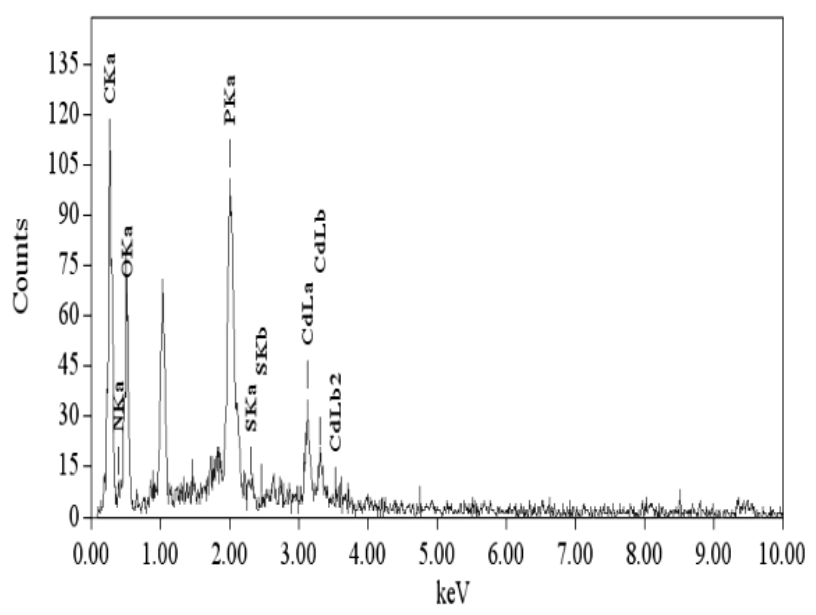

Figure 5. Energy dispersive X-ray spectra of Pseudomonas aeruginosa KUCd1 cells grown in TMMG medium with Cd (3 mM) for $48 \mathrm{~h}$ showing intracellular presence of cadmium. 

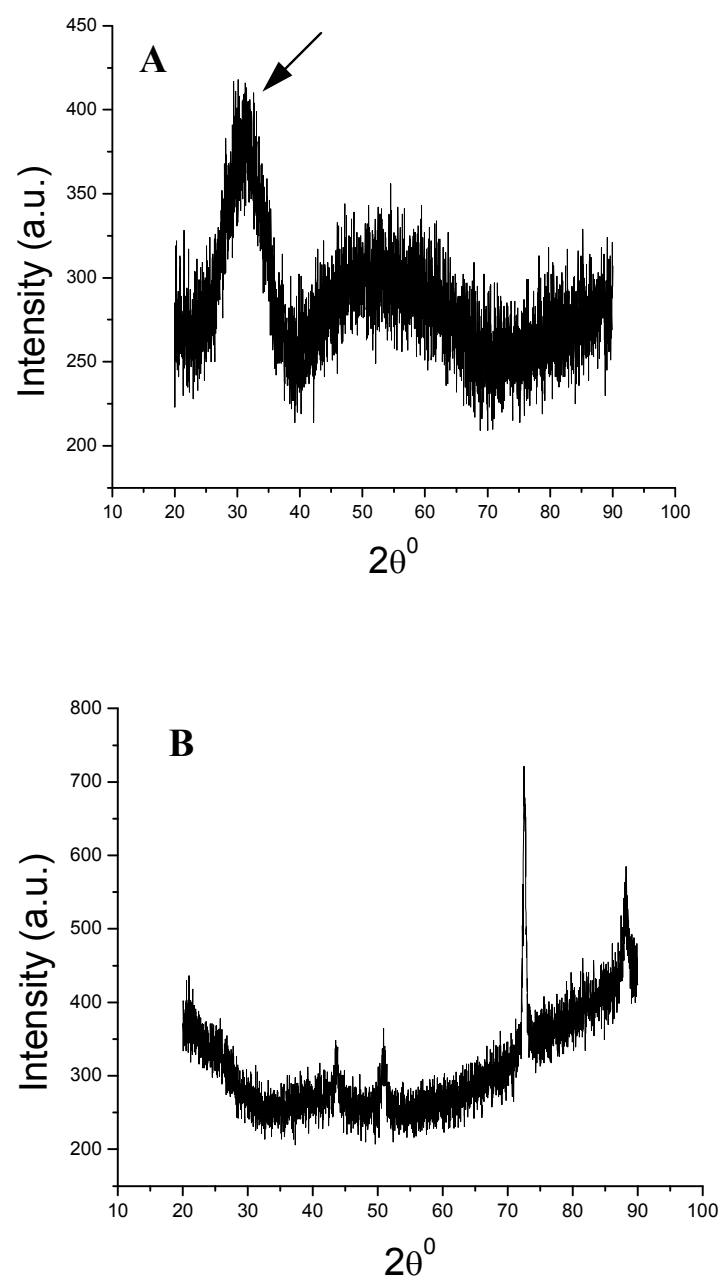

Figure 6. X-ray diffraction spectra of dried powdered Pseudomonas aeruginosa KUCd1 cells grown for $48 \mathrm{~h}$ in TMMG medium with 3 $\mathrm{mM} \mathrm{Cd}$ (A) or Cd-free control (B). Arrow shows the peak of CdS.

\section{ACKNOWLEDGEMENTS}

The work was supported by the grant received from the University of Kalyani. The authors also acknowledge the help received from Indian Institute of Chemical Biology, Kolkata, India for TEM and EDXS studies; and Indian Association for
Cultivation of Science, Kolkata, India, for X-ray diffraction study.

\section{RESUMO}

\section{Pseudomonas aeruginosa KUCd1, um possível candidato para biorremediação de cádmio}

Descreve-se a cepa Pseudomonas aeruginosa KUCd1 resistente a cádmio $(8 \mathrm{mM})$ que apresenta elevado acumulo de cádmio em condições de aerobiose in vitro. Durante a fase ativa de multiplicação, a cepa apresentou capacidade de remover mais de $75 \%$ e $89 \%$ de cádmio solúvel do meio de cultura e da água residual industrial contendo $\mathrm{Cd}$. A microscopia eletrônica de transmissão (TEM) e espectroscopia de raio $\mathrm{X}$ energia dispersiva indicaram a presença de $\mathrm{Cd}$ nas células na fase estacionária intermediária. O fracionamento celular indicou serem a membrana e o periplasma os pontos de maior acúmulo. A natureza química do $\mathrm{Cd}$ acumulado foi avaliada através de análise de difração de Raios X.

Palavras-chave: Pseudomonas aeruginosa, cádmio, biorremediação

\section{REFERENCES}

1. Adamis Paula, D.B.; Panek Anita, D.; Leite Selma, G.F.; Eleutherio Elis, C.A. (2003). Factors involved with cadmium absorption by a wild-type strain of Saccharomyces cerevisiae. Braz. J. Microbiol. 34(1), 55-60.

2. Aiking, H.; Kok, K.; Heerikhuizen, H.V.; Riet, J.V.T. (1982). Adaptation to cadmium by Klebsiella aerogenes growing in continuous culture proceeds mainly via formation of cadmium sulfide. Appl. Environ. Microbiol. 44, 938-944.

3. Aiking, H.; Stijnman, A.; Garderen, C.V.; Heerikhuizen, H.V.; Riet, J.V.T. (1984). Inorganic phosphate accumulation and cadmium 
detoxification in Klebsiella aerogenes NCTC 418 growing in continuous culture. Appl. Environ. Microbiol. 47, 374-377.

4. Andreoni, V.; Colombo, M.; Colombo, A.; Vecchio, A.; Finoli, C. (2003). Cadmium and zinc removal by growing cells of Pseudomonas putida strain B14 isolated from a metal-impacted soil. Anna. Microbiol. $53,135-148$.

5. Bradford, M.M. (1976). A rapid and sensitive method for the quantification of microgram quantities of protein utilizing the principle of protein-dye binding. Anal. Biochem. 72, 248-254.

6. Castro-Silva, M.A.; Lima, A.O.S.; Gerchenski, A.V.; Jaques, D.B.; Rodrigues, A.L.; Souza, P.L.; Rörig, L.R. (2003). Heavy metal resistance of microorganisms isolated from coal mining environments of Santa Catarina. Braz. J. Microbiol. 34 (suppl. 1), 45-47.

7. Gadd, G.M. (1990). Heavy metal accumulation by bacteria and other microorganisms. Experientia 46, 834-840.

8. Goomes, N.C.M.; Mendonca-Hagler, L.C.S.; Sawadis, I. (1998). Metal bioremediation by microorganisms. Braz. J. Microbiol. 29, 85-92.

9. Hassan, M.E.T.; van der Lelie, D.; Springael, D.; Römling, N.; Ahmed, N.; Mergeay, M. (1999). Identification of a gene cluster, czr, involved in cadmium and zinc resistance in Pseudomonas aeruginosa. Gene 238, 417-425.

10. Higham, D.P.; Sadler, P.J.; Scawen, M.D. (1984). Cadmium-resistant Pseudomonas putida synthesizes novel cadmium proteins. Science 225, 1043-1046.

11. Kazy, S.K.; Sar, P.; Asthana, R.K.; Singh, S.P. (1999). Copper uptake and its compartmentalization in Pseudomonas aeruginosa strains: Chemical nature of cellular metal. W. J. Mirobiol. Biotechnol. 15, 599605 .

12. Keasling, J.D.; Hupf, G.A. (1996). Genetic manipulation of polyphosphate metabolism affects cadmium tolerance in Escherichia coli. Appl. Environ. Microbiol. 62, 743-746.

13. Kurek, E.; Czaban, J.; Bollag, J. (1982). Sorption of cadmium by microorganisms in competition with other soil constituents. Appl. Environ. Microbiol. 43, 1011-1015.

14. Les, A.; Walker, R.W. (1984). Toxicity and binding of copper, zinc, and cadmium by the blue-green alga, Chroococcus paris. Water Air Soil Pollut. 23, 129-139.

15. Mitra, R.S.; Bernstein, I.A. (1978). Single-strand breakage in DNA of Escherichia coli exposed to $\mathrm{Cd}^{2+}$.J. Bacteriol. 133, 75-80.

16. Mitra, R.S.; Gray, R.H.; Chin, B.; Bernstein, I.A. (1975). Molecular mechanisms of accommodation in $E$. coli to toxic levels of $\mathrm{Cd}^{+2} . J$. Bacteriol. 121, 1180-1188.

17. Mullen, M.D.; Wolf, D.C.; Ferris, F.G.; Beveridge, T.J.; Fleming,
C.A.; Bailey, G.W. (1989). Bacterial sorption of heavy metals. Appl. Environ. Microbiol. 55, 3143-3149.

18. Nies, D.H. (1992). Resistance to cadmium, cobalt, zinc, nickel in microbes. Plasmid 27, 17-28.

19. Rachlin, J.W.; Warkentine, B.; Jensen, T.E. (1982). The growth responses of Chlorella saccharophila, Navicula incerta, and Nitzschia closterium to selected concentrations of cadmium. Bull. Torrey Bot. Club. 109, 129-135.

20. Ramamoorthy, S.; Kushner, D.J. (1975). Binding of mercuric and other heavy metal ions by microbial growth media. Microb. Ecol. 2, 162-176.

21. Sadouk, A.; Mergeay, M. (1993). Chromosome mapping in Alcaligenes eutrophus CH34. Mol. Gen. Genet. 240, 181-187.

22. Sar, P.; Kazy, S.K.; Singh, S.P. (2001). Intracellular nickel accumulation by Pseudomonas aeruginosa and its chemical nature. Lett. Appl. Microbiol. 32, 257-261.

23. Scott, J.A.; Palmer, S.J. (1990). Site of cadmium uptake in bacteria used for biosorption. Appl. Microbiol. Biotechnol. 33, 221-225.

24. Shapiro, N.; Keasling, J.D. (1996). The recA gene and cadmium toxicity in Escherichia coli K-12. Microbios 86, 23-26.

25. Sharma, P.K.; Balkwill, D.L.; Frenkel, A.; Vairavamurthy, M.A. (2000). A new Klebsiella planticola strain (Cd-1) grows anaerobically at high cadmium concentrations and precipitates cadmium sulfide. Appl. Environ. Microbiol. 66, 3083-3087.

26. Silver, S.; Misra, T.K. (1988). Plasmid mediated heavy metal resistances. Ann. Rev. Microbiol. 42, 717-743.

27. Sinha, S.; Mukherjee, S.K. (2008). Cadmium-induced siderophore production by a high $\mathrm{Cd}$ resistant bacterial strain relieved Cd-toxicity in plants through root colonization. Curr. Micobiol. 56, 55-60.

28. Tebo, B.M. (1995). Metal precipitation by marine bacteria: potential for biotechnological applications. Genet. Eng. 17, 231-263.

29. Waalkes, M.P.; Coogan, T.P.; Barter, R.A. (1992). Toxicological principles of metal carcinogenesis with special emphasis on cadmium. Crit. Rev. Toxicol. 22, 175-201.

30. Wang, C.L.; Maratukulam, P.D.; Lum, A.M.; Clark, D.S.; Keasling, J.D. (2000). Metabolic engineering of an aerobic sulfate reduction pathway and its application to precipitation of cadmium on the cell surface. Appl. Environ. Microbiol. 66, 4497-4502.

31. Wang, C.L.; Michels, P.C.; Dawson, S.C.; Kitisakkul, S.; Baross, J.A.; Keasling, J.D.; Clark, D.S. (1997). Cadmium removal by a new strain of Pseudomonas aeruginosa in aerobic culture. Appl. Environ. Microbiol. 63, 4075-4078.

32. Wilde, E.W.; Benemann, J.R. (1993). Bioremoval of heavy metals by the use of microalgae. Biotechnol. Adv. 11, 781-812. 